\title{
Evaluation of Cajanus Cajan (Pigeon Pea) Genotypes for Agronomic Parameters, Yield and Nutritional Composition at Lowland Areas of Eastern Hararghe Zone, Ethiopia
}

\author{
Tolera Fikadu $^{1^{*}} \quad$ Melese Furgasa $^{2} \quad$ Wubishet Tesfaye $^{3} \quad$ Worku Bekuma $^{4}$ \\ Fedis Agricultural Research Center of Oromia Agricultural Research Institute \\ P.O. box 904, Harar, Ethiopia
}

\begin{abstract}
The study was conducted at lowland of Fedis district during 2018 and 2019 growing season to evaluate the performance of eleven improved pigeon pea genotypes for agronomic yield and nutritional composition. The study revealed that there were no significant differences among pigeon pea genotypes in terms of days to flowering and maturity. However, significantly higher dry biomass and grain yields were obtained. Grain yield ranged from $1,200 \mathrm{~kg} \mathrm{ha}^{-1}$ to $3,030 \mathrm{~kg} \mathrm{ha}^{-1}$ with 16524 having the highest and 11575 had the lowest grain yield. Herbage dry matter yield ranged from 2 to $4.4 \mathrm{t} / \mathrm{ha}$. Genotype 16524 had the highest herbage dry matter yield $(4.4 \mathrm{t} / \mathrm{ha})$. Leaf to stem ratio of local check was $(\mathrm{p}<0.05)$ lower than 11563 genotype but similar to the remaining tested genotypes and seed yield of 16528 genotype was lower than 16524 genotype but similar to the remaining tested genotypes. The crude protein ( $\mathrm{CP} \%$ ), $\mathrm{ASH} \%$, neutral detergent fiber (NDF \%), acid detergent fiber (ADF $\%)$ and Acid detergent lignin (ADL \%) were significantly $(\mathrm{p}<0.05)$ different among genotypes. However, dry matter (DM \%) was not different $(\mathrm{p}>0.05)$ among genotypes. It was concluded that genotype 16524 had performed best most agronomic parameters, biomass yield, seed yield and LSR as compared to the other tested genotypes and adapted check. Thus, it was found promising to be promoted or demonstrated in Eastern Oromia under climatic conditions similar to Fedis.
\end{abstract}

Keywords: Pigeon pea, Genotypes, Dry matter, nutritional composition

DOI: $10.7176 /$ JNSR/12-7-05

Publication date: April $30^{\text {th }} 2021$

\section{Introduction}

The productivity and sustainability of the livestock industry is influenced by technical and socioeconomic factors. One of the major constraints to increasing livestock productivity in this region is the feed supply, followed by animal health and management practices. Poor animal nutrition and productivity arising from inadequate supply and low quality feed are among the major constraints facing livestock production in developing countries (Fekede et al., 2015b). Similarly, feed shortage in terms of both quantity and quality is the leading problem affecting the livestock productivity in Ethiopia (Fekede et al., 2015a). Nutritional factors are the binding constraint to sustaining livestock production in Ethiopia. According to the Country Feed Balance (FAO, 2018) "The difference between availability of feed resources as dry matter (DM), ME and CP and the requirements of all animal species (i.e. feed balance) showed that feed deficiency in Ethiopia is 9 per cent as DM, while ME and CP deficiencies are 45 per cent and 42 per cent deficient respectively". These numbers clearly show the lack of quality feed. Thus integration of livestock and cropping systems is essential for sustainable natural resource management and improved livestock productivity (Alemayehu et al., 2017). The production of adequate quantities of good quality forages, better nutrition, genetics, and the combination of these strategies, are the only way to economically overcome the feed shortage and improve milk/meat production in Ethiopia (Mayberry et al., 2017).

The increased utilization of leguminous and other tree and shrub species, fed as a high quality supplement to the low quality natural pastures and crop residues, has been recognized as one of the means of improving the forage supplies to ruminants in pastoral and crop-livestock systems. Pigeon pea (Cajanus cajan L.) is an important grain legume in Eastern and Southern Africa, Asia and Central America. In Africa it is mostly grown by subsistence farmers in the semi-arid areas due to its drought tolerance (Khaki, 2014). In Ethiopia, pigeon peas (Cajanus cajan) is known as lowland pulse crop which grows in areas where there is high temperature, erratic rainfall, and short growing season (Amsalu et al., 2016). Pigeon pea is hardy, warm-season, drought tolerant, widely adaptable and tolerant to temperatures as high as $35^{\circ} \mathrm{C}$ (Vittal et al., 2004). An average annual rainfall of between 600 and $1000 \mathrm{~mm}$ is most suitable for pigeon pea production (Green Harvest, 2013). The crop can be grown in a wide range of soil textures, from sandy soils to heavy clays; and is well suited for soil with pH range of between 4.5 and 8.4 (Singh and Oswalt, 1992).

The crop is a multi-purpose leguminous crop that plays important role in food security, maintenance of soil fertility through litter fall and nitrogen fixation, provision of fodder for livestock, source of protein, cash income and fuel for small-scale farmers in subsistence-agriculture (Wilson et al., 2012). It is an important grain 
legume, particularly in rain-fed agricultural regions in the semi-arid tropics, as well as an excellent, high-protein cover/forage for livestock (Pal et al., 2011) which can be intercropped or grown in mixed cropping systems with cereals or other short duration annuals (Joshi et al., 2001). The main products of pigeon pea are dry grain, green pods and fodder (Mergeai et al., 2001). The leaves and immature stems can be cut and used as a green manure (OAF, 2015).However, this fodder tree was not available in Eastern Oromia; where livestock is greatly dependent on crop residues for feed and the farmers usually harvest fodder from thinned crop plants, weeds, and defoliated leaves. Although this improved fodder tree showed high potential under different research centers, their performance in the study area was not documented. Although pigeon pea can adapt well under drought conditions there is a great variability of different genotypes for yield under the drought conditions (Deshmukh and Mate, 2013). Therefore, the study was conducted to determine the performance of different pigeon pea genotypes and to select/identify the high yielding genotype (s) in dry matter yield and nutritional qualities suited at lowland agro-ecologies of Eastern Oromia.

\section{MATERIALS AND METHODS}

\subsection{Description of the study area}

The study was conducted under rain-fed conditions during 2018 and 2019 growing season at Fedis Agricultural Research Center, on Boko station. It is $550 \mathrm{~km}$ to the East of Addis Ababa and $24 \mathrm{~km}$ southeast of Harari city. The experimental site is situated at an altitude of $1500 \mathrm{~m}$ above sea level, (Fuad et al., 2018). The amount of rainfall varies between 650 and $750 \mathrm{~mm}$, while the average temperature ranges between 25 and $30{ }^{\circ} \mathrm{C}$ (Zenna, 2016). Vertisols and Afilsols soil type are common to the area (FARC, 2013).

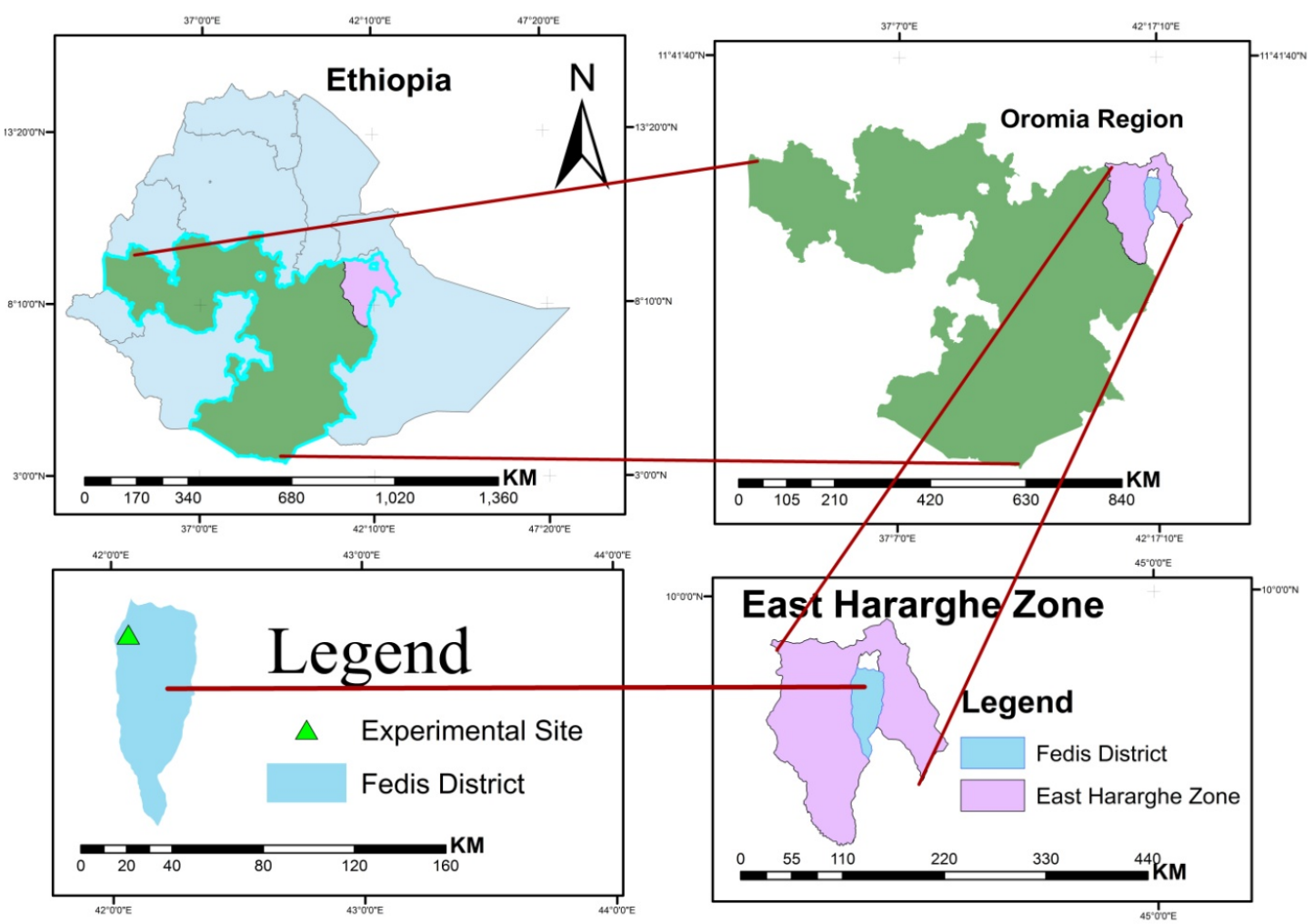

Fig. 1. Map of the experimental site

\subsection{Experimental Design and Treatments}

The experiment was conducted using randomized complete block design consisting of 3 replications. The plots were $3.75 \mathrm{~m}^{2}$ each with a space of one meter from each plot and with a spacing of $0.75 \mathrm{~m}$ between rows. The plot size consisted of four rows of $3 \mathrm{~m}$ long and inter and intra row spacing of $0.75 \times 0.5 \mathrm{~m}$, respectively. The seeds of ten pigeon pea accessions $(16555,16526,16527,11575,16524,16528,16520,11566,11563$ and 16537) were obtained from international livestock research institute (ILRI) and one local check used. Land was ploughed and harrowed, and then two to three seeds of pigeon pea were planted per hole. Seedlings were thinned down to one plant per hole to ensure uniform plant stand per hole. Weeding was done when necessary. Neither fertilizer nor herbicide was applied to the plots. 


\subsection{Data collection}

Days to flowering, plant height and biomass yield were collected when the plants attained 50\% flowering. Data were collected from the two middle rows from each plot. The total harvest per two rows of leaf and stem fresh biomass was weight and about $500 \mathrm{~g}$ of sub sample taken from each plot and chopped in short length for dry matter determination, and also for laboratory analysis. Sub-samples of air-dried harvested forage were bulked and taken to the Nutrition Laboratory of Haramaya University for analysis of dry matter (DM \%), ASH\%, crude protein $(\mathrm{CP} \%)$, neutral detergent fiber (NDF \%), acid detergent fiber (ADF \%) and Acid detergent lignin (ADL $\%)$.

The height of plant at each plant was measured by measuring all the samples harvested for dry matter determination and the average height of all the plants taken as a height of plant at each plant. Seed yield and days to maturity were sampled when the pods attained physiological maturity. Seed yield and days to maturity were sampled when the pods attained physiological maturity.

\section{Statistical Analysis}

Data was analyzed using the Statistical Analysis Software to perform ANOVA (SAS 9.1) in a randomized complete block design. Means of all treatments were calculated and the difference was tested for significance using the least significant difference (LSD) test at $\mathrm{p}<0.05$ (Gomez and Gomez, 1984).

\section{RESULTS AND DISCUSSION}

\section{Agronomic Yield Performance of Pigeon Pea Genotypes}

The mean agronomic yield performance of pigeon pea genotypes evaluated was shown in table 1. Results showed that, there was significant difference $(\mathrm{P}<0.05)$ in some of the genotypes evaluated. Analysis of variance showed significance difference $(\mathrm{P}<0.05)$ in leaf and stem dry matter yield among the tested genotypes. The highest leaf dry matter $(4.4 \mathrm{t} / \mathrm{ha})$, stem dry matter $(38.9 \mathrm{t} / \mathrm{ha})$ and seed yield $(3030 \mathrm{~kg} / \mathrm{ha}) \mathrm{were}$ recorded from 16524 genotype, whereas genotype 16528 resulted in the lowest leaf dry matter yield ( $2 \mathrm{t} / \mathrm{ha})$. Increase in dry matter and seed yield might be attributed to more number of branches and number of pods per plant (Rani and Reddy, 2000; Lal and Raina, 2002).The significant differences in those yield components are further explained by Islam and Fakir (2007) that canopy structure, canopy spreading and degree of branching influences most of the yield components such as number of pods per plant. The significant differences were also might be due to reaction of different landraces in temperature and photoperiod. The photoperiod and temperature effects on flowering and plant canopy development in pigeon pea make agronomists to choose cultivars that adapt and perform well to specific climatic conditions (Silim et al., 2005).

The study showed that there were no significant differences $(\mathrm{P}>0.05)$ among pigeon pea genotypes in terms of days to flowering and maturity. Almost all the genotypes tested in this study were found to be short duration genotypes which took 10-150 days to reach physiological maturity. However, significant differences (P $<0.05)$ were observed among genotypes for plant height. Pigeon pea genotypes in this study were generally tall, probably due to influence of exposure to long-day conditions and environment (Egbe and Vange, 2008). The difference in plant heights might be also due to sensitivity to photoperiod among genotypes whereby they reacted differently and exposure to long day condition and temperature sensitivity among genotypes. This is evidenced by Robertson (2001), that genotypic differences are influenced by the temperature in terms of plant height. The results also indicated that leaf to stem ratio of local check was $(p<0.05)$ lower than 11563 genotype but similar to the remaining tested genotypes and seed yield of 16528 genotype was lower than 16524 genotype but similar to the remaining tested genotypes. Significantly lower seed yield was obtained by 16528 genotype, whereas the remaining genotypes not different $(\mathrm{p}>0.05)$ in seed yield. In general, genotypes 16524,11563 and 16537 performed better than local check in most agronomic and yield parameters. The highest herbage dry matter yield performance of 16524 genotype revealed that this genotype is better adapted and performed well as compared to the tested genotypes. 
Table 1. Agronomic and yield performances of pigeon pea genotypes tested at Fedis during 2018 and 2019 growing season

\begin{tabular}{|c|c|c|c|c|c|c|c|}
\hline $\begin{array}{l}\text { Genotypes } \\
\text { (treatments) }\end{array}$ & DF & $\mathrm{PH}(\mathrm{cm})$ & LDM t/ha & $\begin{array}{l}\text { SDM } \\
\mathrm{t} / \mathrm{ha}\end{array}$ & $\begin{array}{l}\mathrm{SY} \\
\mathrm{kg} / \mathrm{ha}\end{array}$ & DM & LSR \\
\hline 16555 & 103.7 & $168 \mathrm{~cd}$ & $2.7 b$ & $25.6 \mathrm{abc}$ & $2510 \mathrm{ab}$ & 152.3 & $10.57 \mathrm{ab}$ \\
\hline 16526 & 98.3 & $169.7 \mathrm{bcd}$ & $2.8 \mathrm{~b}$ & 26.9abc & $2200 \mathrm{ab}$ & 146 & $10.4 \mathrm{ab}$ \\
\hline 16527 & 98.3 & $193.4 \mathrm{a}$ & $2.8 \mathrm{~b}$ & $34.3 \mathrm{ab}$ & $1870 \mathrm{ab}$ & 142.7 & $8.3 \mathrm{ab}$ \\
\hline 11575 & 108 & $181 \mathrm{ab}$ & $2 \mathrm{~b}$ & $21.6 b c$ & $1200 b$ & 148 & $9.2 \mathrm{ab}$ \\
\hline 16524 & 111 & $180.8 \mathrm{ab}$ & $4.4 \mathrm{a}$ & $38.9 \mathrm{a}$ & $3030 a$ & 151 & $12.1 \mathrm{a}$ \\
\hline 16528 & 109.3 & $143.4 f$ & $2 b$ & $26.2 \mathrm{abc}$ & $1270 b$ & 142 & $8.8 \mathrm{ab}$ \\
\hline 16520 & 95.7 & $163.6 \mathrm{df}$ & $2.7 b$ & $27.3 \mathrm{abc}$ & $2260 \mathrm{ab}$ & 144.7 & $10.1 \mathrm{ab}$ \\
\hline 11566 & 109.3 & $128.1 \mathrm{~g}$ & $2.3 b$ & $21.8 \mathrm{bc}$ & $1730 \mathrm{ab}$ & 144.3 & $10.43 \mathrm{ab}$ \\
\hline 11563 & 103.7 & $176.5 \mathrm{bc}$ & $3.06 \mathrm{ab}$ & $26.1 \mathrm{abc}$ & $2290 \mathrm{ab}$ & 148 & $12 \mathrm{a}$ \\
\hline 16537 & 95.3 & $152.8 \mathrm{ef}$ & $2.96 \mathrm{ab}$ & $27 \mathrm{abc}$ & $2330 \mathrm{ab}$ & 145.3 & $10.87 \mathrm{ab}$ \\
\hline Local check & 107 & $178.8 \mathrm{bc}$ & $2.8 \mathrm{~b}$ & $38.92 \mathrm{a}$ & $2280 \mathrm{ab}$ & 184.3 & $7.9 \mathrm{~b}$ \\
\hline Grand mean & 103.61 & 166.91 & 2.789 & 27.75 & 2.0885 & 146.67 & 10.309 \\
\hline CV (\%) & 12.32 & 4.46 & 32.38 & 31.84 & 31.99 & 4.75 & 21.95 \\
\hline LSD (0.05) & NS & 12.681 & 0.737 & 7.15 & 1.49 & NS & 1.847 \\
\hline
\end{tabular}

Means with the same letter in the same column are not significantly $(\mathrm{p}<0.05)$ different. $\mathrm{DF}=$ days to flowering, $\mathrm{PH}=$ plant height, $\mathrm{LDM}=$ leaf dry matter, $\mathrm{SDM}=$ stem dry matter, $\mathrm{SY}=$ seed yield, $\mathrm{DM}=$ day to maturity, $\mathrm{LSR}=\mathrm{leaf}$ to stem ratio, $\mathrm{NS}=$ none significant. $\mathrm{LSD}=$ Least significant difference; $\mathrm{CV}=$ coefficient of variance

\section{Chemical composition of Pigeon Pea Genotypes}

The chemical compositions of eleven pigeon pea genotypes are presented in table 2 . The crude protein $(\mathrm{CP})$, ash neutral detergent fiber, acid detergent fiber and acid detergent lignin were significantly $(\mathrm{p}<0.05)$ different among genotypes. However, dry matter (DM \%) was not different ( $>00.05)$ among genotypes. In the current study, genotypes 11566 and 16524 had significantly higher crude protein content than 16555, 16528 and 16520 genotypes. However, except with these three genotypes the crude protein content of the remaining genotypes was almost similar to 11566 and 16524 genotypes. Significantly the higher ash content was obtained by 16528 and 16527 genotypes whereas the lower content was observed by 11575 and 16555 genotypes.

Contents of NDF was also significantly different $(\mathrm{P}<0.05)$ among the evaluated pigeon pea genotypes. The higher NDF was recorded for 16520 and 16528 followed by 16555 genotype while the lower value was observed by 16524 and 11563 genotypes. Similarly, significantly the higher ADF was obtained by 16528 and 16520 genotypes where as the lower value was observed from 11563 genotype. Content of ADL also significantly varied $(\mathrm{P}<0.05)$ among genotypes, where significantly higher value was recorded for $11575,16520,12.936$ and 16528 genotypes and significantly lower value was obtained by the remaining tested pigeon pea genotypes.

In general, genotype16524 showed significantly higher herbage dry matter and seed yield performance. Moreover this genotype had higher nutritional qualities as compared to the tested pigeon pea genotypes.

Table 2. Herbage Chemical composition of Pigeon pea genotypes

\begin{tabular}{lllllll}
\hline Treatments & DM $\%$ & Ash $\%$ & CP\% & NDF\% & ADF\% & ADL $\%$ \\
\hline 16555 & 92.422 & $9.075 \mathrm{~d}$ & $19.234 \mathrm{~b}$ & $63.182 \mathrm{ab}$ & $36.712 \mathrm{c}$ & $10.842 \mathrm{~b}$ \\
16526 & 92.33 & $10.164 \mathrm{~b}$ & $21.78 \mathrm{ab}$ & $58.606 \mathrm{~cd}$ & $33.22 \mathrm{e}$ & $11.576 \mathrm{~b}$ \\
16527 & 92.882 & $10.425 \mathrm{ab}$ & $21.015 \mathrm{ab}$ & $57.285 \mathrm{~d}$ & $36.215 \mathrm{~cd}$ & $11.326 \mathrm{~b}$ \\
11575 & 92.212 & $8.954 \mathrm{~d}$ & $21.94 \mathrm{ab}$ & $56.643 \mathrm{de}$ & $41.351 \mathrm{~b}$ & $13.076 \mathrm{a}$ \\
16524 & 92.45 & $10.232 \mathrm{~b}$ & $23.282 \mathrm{a}$ & $48.955 \mathrm{f}$ & $33.96 \mathrm{de}$ & $10.705 \mathrm{~b}$ \\
16528 & 92.011 & $10.706 \mathrm{a}$ & $19.136 \mathrm{~b}$ & $64.972 \mathrm{a}$ & $44.411 \mathrm{a}$ & $12.784 \mathrm{a}$ \\
16520 & 92.223 & $9.656 \mathrm{c}$ & $19.113 \mathrm{~b}$ & $64.985 \mathrm{a}$ & $43.865 \mathrm{a}$ & $13.214 \mathrm{a}$ \\
11566 & 92.324 & $9.456 \mathrm{c}$ & $23.578 \mathrm{a}$ & $61.013 \mathrm{bc}$ & $33.747 \mathrm{e}$ & $11.361 \mathrm{~b}$ \\
11563 & 92.427 & $10.335 \mathrm{~b}$ & $22.01 \mathrm{ab}$ & $45.612 \mathrm{f}$ & $30.343 \mathrm{f}$ & $11.453 \mathrm{~b}$ \\
16537 & 92.625 & $9.419 \mathrm{c}$ & $21.799 \mathrm{ab}$ & $57.629 \mathrm{~cd}$ & $40.115 \mathrm{~b}$ & $11.231 \mathrm{~b}$ \\
Local check & 91.739 & $9.454 \mathrm{c}$ & $21.675 \mathrm{ab}$ & $53.745 \mathrm{e}$ & $40.208 \mathrm{~b}$ & $12.936 \mathrm{a}$ \\
\hline Grand mean & 92.331 & 9.807 & 21.324 & 57.51 & 37.65 & 11.844 \\
CV $(\%)$ & 0.69 & 1.41 & 6.96 & 2.69 & 2.86 & 3.98 \\
LSD $(0.05)$ & $\mathrm{NS}$ & 0.138 & 1.48 & 1.55 & 1.0765 & 0.472 \\
\hline
\end{tabular}

Means within the same column followed by the same letter or by no letters of each factor do not differ significantly at $5 \%$ probability level. $\mathrm{DM}=$ dry matter, $\mathrm{CP}=$ Crude protein, $\mathrm{NDF}=$ neutral detergent fiber; $\mathrm{ADF}$ $=$ acid detergent fiber; NS = none significant. $\mathrm{LSD}=$ Least significant difference; $\mathrm{CV}=$ coefficient of variance 


\section{Conclusions}

The study shows that genotype 16524 performed best in biomass and seed yield and had high nutritional qualities among the tested genotypes. These results suggested that pigeon pea has the potential to provide forage of high quality and adequate quantity for livestock when other summer forages are unproductive. Hence, genotype 16524 is recommended for promotion in lowland environments of East Hararghe zone. Moreover, future research should be focused on breeding programs to identify extra short duration pigeon pea and evaluate its yield potential in lowland areas of Eastern Hararghe zone.

\section{Acknowledgements}

The authors want to thank the Oromia Agricultural Research Institute (OARI) and Fedis Agricultural Research Center (FARC) for financial and technical support.

\section{References}

Alemayehu Mengistu, Gezahagn Kebede, Fekede Feyissa and Getnet Assefa. 2017. Review on Major Feed Resources in Ethiopia: Conditions, Challenges and Opportunities. Acad Res J Agric Sci Res 5: 176-185.

Amsalu, B, Tumsa, K., Negash, K., Ayana, G., Fufa, M., Wondemu, A., Teamir, M., and Rubyogo, J.C. 2016. Lowland pulses research in Ethiopia: achievement, challenges and future prospect .pp 44-60.

Belete, S., Abubeker, H., Abule, E. and Nura, A. (2012): Performance of Arsi-Bale kids supplemented with graded levels of pigeon pea in dry season in Mid Rift Valley of Ethiopia. African Journal of Agricultural Research, 8 (20):2366-2370.

Deshmukh and Mate, 2013. Evaluation of pigeon pea genotypes for morphological traits related to drought tolerance legumes. Res 32 (1):46-50.

Egbe, O.M. and T. Vange. 2008. Yield and agronomic characteristics of 30 pigeon pea genotypes at Otobi in Southern Guinea Savanna of Nigeria. Life Science Journal 5(2):70-80.

FAO. 2018. Ethiopia: Report on feed inventory and feed balance, 2018. Rome, Italy. 160 pages. Licence: CC BY-NC-SA 3.0 IGO.

FARC (Fedis Agricultural Research Center). 2013. Soil Chemical Analysis: Regional Review, Zeway, Ethiopia.

Fekede Feyissa, G Assefa, G Kebede, A Mengistu and D Geleti, 2015a. Cultivated Forage Crops Research and Development in Ethiopia. In: Alemu Yami, Getnet Assefa and Lemma Gizachew (eds.), 2015. Pasture and Rangeland Research and Development in Ethiopia. Proceedings of a workshop organized by Ethiopian Society of Animal Production (ESAP) and held 03 February 2014 at EIAR, Addis Ababa, Ethiopia.

Fekede Feyissa, G Kebede and G Assefa, 2015b. Dynamics in Nutritional qualities of tef and wheat straws as affected by storage method and storage duration in the central highlands of Ethiopia. African J Agric Res, 10: 3718-3725.

Fuad Abduselam, Samuel Tegene, Zeleqe Legese, Fikadu Tadesse, Alemayehu Biri and Taye Tessema. 2018. Evaluation of Early Maturing Sorghum (Sorghum bicolor(L.)Moench) Varieties, for Yield and Yield Components in the Lowlands of Eastern Hararghe. Asian Journal of Plant Science and Research, 8(1):4043.

Gomez, K. A. and Gomez, A. A. 1984. Statistical procedures for agricultural research, 2nd edition. John Viley and Sons Inc., New York.

Khaki N. 2014. Evaluation of Malawi pigeon pea (cajanus cajan 1) accessions for tolerance to moisture stress and superior agronomic traits in Uganda.

Lal SK, Raina R (2002). Inter-relationships between yield and its component traits in long duration hybrid in pigeon pea. Ann. Agric. Res. New Series 23:101-104.

Mayberry D, Ash A, Prestwidge D, Godde CM, Henderson B, Duncan AJ, Blummel M, Reddy YR and Herrero M. 2017. Yield gap analyses to estimate attainable bovine milk yields and evaluate options to increase production in Ethiopia and India. Agricultural Systems, 155: 43-51. https://doi.org/10.1016/j.agsy.2017.04.007.

Mergeai, G., Kimani, P., Mwangombe, A., Olubayo, F., Smith, C., Audi, P., Baudoin, J.-P., Le Roi, A., 2001. Survey of pigeonpea production systems, utilization and marketing in semi-arid lands of Kenya. Biotechnology, Agronomy, Society and Environment, 5(3): 145-153.

Minja, E. M. (2001). Yield losses due to field pests and integrated pest management strategies for pigeonpea- a synthesis. In: S.N. Silim, G. Mergeai, and P.M. Kimani, (eds). Proceedings of the Regional Workshop on Status and Potential of Pigeonpea in Eastern and Southern Africa 2000, Nairobi, Kenya., 48-54.

OAF, 2015. Pigeon Pea - Long Rain Season, Kenya (2014). Farmers First, One Acre Fund, May 2015

Onwueme, IC and Sinha TD (1991). Field Crop Production in Tropical Africa. CTA, Ede, The Netherlands $8: 552$

Pal D, Mishra P, Sachan N, Ghosh AK (2011) Biological activities and medicinal properties of Cajanus Cajan (L) Millsp. J Adv Pharm Technol Res 2(4):207-214. 
Silim, S. N, Bramel, P. J, Akonaay, H. B, Mligo, J. K, \& Christiansen, J. L. (2005). Crop - ping systems, uses, and primary in situ characterization of Tanzanian pigeonpea (Ca - janus cajan (L.) Millsp.) landraces. Genet. Res. Crop Evol. , 52, 645-654.

Singh, F, \& Oswalt, D. L. (1992). Insect pests of pigeonpea. In: Pest management Skills Development Series ICRISAT, Patancheru, India. (12), 6-20.

Wilson C, Hui D, Nwaneri E, Wang J, Deng Q, Duseja D, Tegegne F. Effects of planting dates, densities, and varieties oecophysiology of pigeonpea in the southeastern United States. Agr Sci. 2012;2:147-152.

Zenna T. 2016. Business and management consultancy (TZBMC), CARE ABDISHE/linking initiatives, stakeholders to achieve gender-sensitive livelihood security (LINKAGES) project end line evaluation report. 